\title{
11
}

\section{Science, context and professional ethics}

\author{
Ruth Chadwick
}

"There is a central core of universal values that any truly modern society must possess, and that science promotes. These are rationality, creativity, the search for truth, adherence to codes of behavior, and a certain constructive subversiveness" (Serageldin 2002)

\section{Science and the ethics of distrust}

In the last decade ethical issues relevant to scientists as professionals have come very much to the fore, although they have not, typically, been considered under the guise of professional ethics as such. Rather, appeal has been made to problems that have arisen in the context of, for example, genetically modified foods and the BSE case. These cases involved both public concerns over the profit motive prevailing in the research and policy agenda; and anxieties about the unpredictability of long-term consequences. Can the framework of professional ethics shed any light on these issues?

It might be relevant to consider the wider context of distrust in the professions (Pellegrino 1991). Both sociological and philosophical criticism (cf. Koehn 1994) have constituted aspects of this phenomenon, apparent in the late 1980s and early 1990s. An ethic of distrust proceeds by attempting to regulate more closely the activities of professionals, by increased external monitoring and demands for accountability. According to one view (Veatch 1991) this approach wins the day by default because the notion of an ethics of trust is not only difficult to sustain: it is actually incoherent.

Robert Veatch attacks what he sees as the three arguments supporting an ethic of trust: (1) that professionals serve the client's interest; (2) that professionals can present value-free facts to the client; (3) that professionals should act on a set of virtues inherent in the profession. Veatch argues that modern professionals ought not to know what the client's interests really are - the most they can know is what the client's interests are in one particular area of life. Whereas medical professionals might be primarily concerned with promoting health, for example, health might not be the top priority for a patient (Goldman 1992). Veatch further argues that professionals cannot present value-free facts; and that it is a serious mistake to think that any given profession is associated with one particular conception of virtue. These points are very apposite for a consideration of the ways in which ethical considerations enter debates about science, in the light of, for example: the questioning about the extent to which science serves society; debates about value neutrality in science; and the extent to which scientific 'truth' is an unquestionable good. But does science constitute a 'profession' in the relevant sense to make it worthwhile looking at it through the lens of professional ethics?

\footnotetext{
\# Lancaster University, Furness College, Lancaster LA1 4YG, United Kingdom. E-mail:

R.Chadwick@lancaster.ac.uk
} 


\section{Science as a profession?}

There are different approaches to giving an account of what it means to be a profession: the 'defining characteristics' approach and the 'process' approach. The 'defining characteristics' approach, again, has a narrow and a wide version - in a wide sense 'profession' simply means someone's occupation; in a narrower (more interesting) sense it refers to a certain kind of activity, one carrying with it a certain status and associated with a particular ethic. Traditionally a profession has been marked out by a body of knowledge, mastery of which (at least partly) regulated entrance to its ranks; and by an ideal of service (Airaksinen 1994). Since the body of knowledge has the potential to confer power, money and status, professionals are expected to use their skills for the benefit of the community. Those groups which have long been secure in their recognition as professions, the so-called liberal or 'learned' professions such as medicine, divinity and the law, have also been characterized by a considerable degree of authority and autonomy in their practice. Along with the autonomy of the individual professional, professional bodies have also been accorded a significant degree of autonomy in controlling both accesses to the profession and professional conduct.

Taking into account the provisional nature of scientific knowledge, science as a profession can apparently satisfy the 'body of knowledge' criterion: the ideal of service, however, is less clear. Service to whom? This point may depend on the context in which the scientist works, and this is a very important consideration with regard to a discussion of the ethical issues. One of the problems, arguably, with current scientific practice is the rival claim of academia, industry and government as the context in which scientific research takes place.

If we look at a process account of profession, in terms of how an occupational group achieved a certain status (cf. Freidson 1994), rather than the set of characteristics approach, it is arguable that scientists have achieved a position of power, not only in having far-reaching effects on society through scientific advance itself but also in having considerable influence as government advisers and being able to command the highest salaries among academics.

Traditional classifications of professions have been subject to two contrasting trends: first, the attempt by some groups for recognition as professions or neoprofessions; and second, challenges to the notion of professionalism either because of its conceptual inadequacy, or on the grounds of its social consequences. I shall set aside the former for present purposes, but I do want to say something about the second. One reason for the challenge to the concepts of profession and professionalism is that critical, reflective professionals, with autonomy over their practice, may be seen as a threat (Williams 1996). A second reason is connected with the potential for professions to become self-serving elite's (Freidson 1994; Illich 1997). In response to this situation there has been an attempt to replace the focus on professionalism with a focus on competencies. It may not be so easy, however, to dispense with the notions of 'profession' and 'professionalism'. J.K. Davis, for example, has argued that for the professional it would not be sufficient that a client was satisfied, if the professional him- or herself felt that the service was below standard. For the professional, however, it is more than simply doing a competent job: a worker becomes a professional by professing reasons for doing their work in a certain way (Davis 1991a). 
We cannot assume, however, that the area of 'competence' is ethically neutral, while values come into the realm of 'reasons for action'. Certainly in the case of science, while there may be dispute about what we mean by calling science a profession, it is increasingly recognized that while scientific competence may be necessary it is not sufficient for the 'good' scientist. A recent article in The Daily Herald (2003??) said:

"Here are three biology terms: endoskeleton, enzyme, epidermis. If you're serious about a career in biology, add one more item to the list: ethics". Here ethics appears among the basic competencies for a biological career.

What I want to suggest is that it may be enlightening to consider science as a profession and to look at it through the lens of professional ethics. It enables us to put aside the specific 'scandals' that have, supposedly, given rise to the distrust of science and to look at the wider context of the distrust of professional power, the reasons for it, and the proposed solutions, such as the approach to grounding trust in the professions anew. Koehn (1994) has argued that to do this is important because professions represent the mechanism chosen by Anglo-American morality for providing people with goods such as health and justice, and if professionals are not trustworthy, where are we to turn for help? For health and justice are not goods that are readily dispensed with. Does the same apply in the case of science? This depends on identifying the relevant good. For Koehn, the challenge is to show not only that there are grounds for trust in the professions because they provide people with such goods, when they lack them, but also that they do not violate the requirements of ordinary morality (Koehn 1994). There is a connection here with current policies of trying to re-establish trust in science by, for example, the developments we have seen starting from public understanding of science, moving through public consultation, to public 'engagement'. At what stage in the process should the public be engaged? There has been debate about the limitations of involving the public only at the 'downstream' stage of the impact, implications or applications of science, rather than at the 'upstream' stage of debating what scientific research should be carried out. It would be possible to move even further back, however, to consider what the 'good' of science is: is that for scientists themselves to determine?

Although it seems that there are close connections between the debates in professional ethics as a whole and those concerned with the ethics of science, it is clear that context, as we have already noted, is important. In so far as scientists are academics, the relevant questions of professional ethics will be common to other academic disciplines - I am thinking here of the avoidance of plagiarism, for example. In this paper however I want to consider whether and to what extent there are issues that are specific to science and the relevance of context in addressing them. With that in mind I shall move on to the problems of professional ethics.

\section{Professional ethics and science}

Problems of professional ethics typically fall into two broad categories, but both arise essentially from professional power. The first is concerned with the professional-client relationship, while the second relates to the role of professions and professionals in society as a whole.

\section{The professional-client relationship}

Although an ideal of service is supposed to provide a safeguard to promote the use of professional expertise to help rather than harm, specialist knowledge, to which 
professionals have access and clients do not, does give the professional power, and the client is thus placed in a vulnerable position. One caveat however (Langan 1991) is that the paradigm of a relationship between two individuals is inadequate because it overlooks those professions which do not, or not substantially, conform to this pattern, such as teaching, which may be but commonly is not done on a one-to-one basis. Although there are ethical issues arising in relation to science concerning treatment by researchers of individuals, e.g. in human subjects research, science per se also does not conform to this pattern, having as it does an impact on society as a whole.

The second category of problems is more concerned with the role and image of professionals in society. While it may be true (Pellegrino 1991) that there has always been a tendency towards distrust of professionals, this has been exacerbated by social and political developments. The trend towards client autonomy; attempts by government to curb the independence and privilege of professionals; media criticism have all had their effect.

\section{Professions and science in society}

Sociological critique has suggested that professions, rather than being essentially moral enterprises, are in fact effective monopolistic institutions and that the professed commitment to ethical ideals, rather than conferring legitimacy on the profession, is nothing more than ideology. Ivan Illich (1997) famously termed the mid-twentieth century the age of 'disabling' professions: far from using their knowledge to serve, they had become forms of control, claiming the authority to determine human needs. This critique is one that has been levelled against science, leading to calls for the democratization of science.

There are several aspects to this criticism of science:

(a) the belief that scientific progress is inevitable is under challenge, and indeed, that there is such a thing as progress

(b) the attempt to draw a distinction between the pursuit of knowledge and questions about its use has been undermined - it is no longer adequate for the scientist to say 'I just do the science: it is for society to decide what to do with the knowledge'

(c) perceived undesirable consequences of scientific developments 'going too far' have led people to fall back on ideas about the natural and familiar.

What I want to suggest is that while the tendency has been to address these questions by trying to make science and scientists more accountable, this has been inadequate. We have seen in the last ten years moves in many countries to do this in a number of ways, for example by allowing other forms of expertise, such as ethical and lay expertise, to influence debates in the policy area. This has had the effect of opening up the whole notion of expertise and what counts as a relevant 'body of knowledge' for particular purposes. The approach, however, has been what I call 'external' and again I think here the discussion that has taken place in professional ethics about internal and external ethical approaches might offer some useful insights.

\section{Theoretical perspectives: internal and external}

\section{A self-derived ethic?}

Some critics have taken issue with a self-derived ethic which permits professionals to be guided by standards other than those of ordinary morality. "Problems in professional ethics typically arise when the values dominant within particular professions come into conflict with other values in the course of practice. 
Professionals are likely to perceive these values as dominant where others may not" (Goldman 1992, p. 1018). While few might subscribe to the view that nothing else can compete with the value of a new fact (quoted in Vyvyan 1971), a self-derived ethic might take a number of forms. In one form it is associated with the idea that there are certain ways of behaving appropriate to different roles, which diverge from those suited to people who do not fill that role. For example, it might be argued that a lawyer is under an obligation, arising out of the lawyer's role, to achieve the best result for a client even if that conflicts with what he or she believes as a private individual.

Another form which a self-derived ethic might find expression in is a code of professional conduct or code of ethics. The possession of a code of professional conduct has been pivotal in debates about what constitutes a profession. Such a code can fulfil a variety of functions: offering a public statement of ideals and values; providing a disciplinary mechanism for a professional body; reassuring the public that the profession upholds certain standards; and educating members of the profession to 'think like' others in the group (Davis 1991b).

The standards incorporated in a code may be either higher or lower than the standards of ordinary morality. Professionals have traditionally been prevented from doing things which people in other spheres of activity are permitted to do e.g., advertising. This arises out of the purported commitment to serve first the interests of clients, rather than their own profit. On the other hand this same commitment can act as a shield to protect professionals from the criticism that they do things which would be frowned on in terms of ordinary morality e.g., lying to clients or physically hurting them in order to promote some further end identifiable as being in the client's interests (Häyry and Häyry 1994).

Criticism of a self-derived professional ethic, whether in the form of role ethics or a code of conduct, is based on arguments that if an action is morally right it should be susceptible of justification by the same moral arguments that apply to the behaviour of any other member of society - professionals should not require special ethical norms to be determined by themselves. For it is not clear how such norms could be justified if not by common moral principles (Goldman 1992).

How would these considerations be applicable to science? There have been attempts to outline sets of ethical principles for scientists. One example is the HUGO Ethics Committee Statement on the Principled Conduct of Genetics Research (1996). Drawn up as it was by the Ethics Committee of the Human Genome Organisation, it is not entirely self-derived because the Ethics Committee members are not all members of HUGO, but its primary audience is scientists who are members of that organization, and who are engaged in genetic research. (It is worth mentioning however, that it is to a large extent in the context of genetics that recent debates about the ethical conduct of science have been situated). This statement is sometimes described as a 'Ten Commandments' or the 'Ten C's'. I shall not enumerate all the principles. As the statement relates to human genetic research, several of the principles relate to treatment of research participants, and I want to confine myself to science per se. The first principle concerns competence, which is said to be an essential prerequisite for research, and which has been mentioned above. Others which I think are relevant to the present discussion relate to communication, collaboration and conflict of interest.

Communication is relevant to being 'accountable' (cf. Holdsworth 1994) but the HUGO Ethics Committee states that "Communication is a reciprocal process; researchers must strive to understand as well as to be understood". It is stated that 
"[C]ollaboration ... in the free flow, access, and exchange of information is essential not only to scientific progress but also for the present or future benefit of all participants". It is this principle of ethical science that is held to be under threat from scientists' loyalty to particular organizations, and this explains the importance of the principle stating that "any actual or potential conflict of interest be revealed at the time information is communicated and before agreement is reached".

\section{Internal goods}

A more interesting distinction between internal and external perspectives is that between internal and external goods. The internal approach might attempt to derive values internal to specific professions by examining the point of those professions, or the relevant good they produce, as outlined above. Rather than accepting them as Illich's 'dominant' professions that take it upon themselves to define human need, the question to ask is: what pre-existing human need or value do and should they serve? This quest might take different forms. The identification of health and justice as goods that cannot readily be dispensed with, because they may be needed by vulnerable people, has been mentioned (Koehn 1994). Or there might be an argument for some intrinsic or 'transcendent' values embedded in a professional activity (Tur 1994). Thirdly, knowing the point of a practice such as a professional activity might point the way to virtues internal to the practice of that activity.

Does this sort of analysis make sense in relation to science? What might qualify as the 'internal good' of science in this sense? The European Group of Advisers to the European Commission in its 1997 Opinion (Group of Advisers on the Ethical Implications of Biotechnology GAEIB 1997) referred to "the fundamental principle of freedom of research, which flows from freedom of thought". It is difficult to accept that freedom of thought can be the relevant internal good, however. Even if there are grounds for thinking that this is a good in itself, it surely cannot be the relevant good in terms of professional ethics. It is not specific to science, and it is not clear, without more, why it should be a service to the community. The relevant internal good must be something that is provided for those affected by the profession rather than a good to members of the profession.

The internal good that science provides must be in some way connected with the purported benefits to society that science can provide. If the matter is looked at in this way, it becomes clear why there are demands for the public to be engaged at a more 'upstream' stage, rather than only after the event, because arguably there are some categories of research that, for social reasons, should not be done. The European Group of Advisers (Group of Advisers on the Ethical Implications of Biotechnology GAEIB 1997) argued that the freedom of thought had to be reconciled with the protection of European citizens and human responsibilities towards animals and the environment, but this is far from being confined to the conduct of research. The very decision to undertake certain research might express discriminatory attitudes, for example, as in research on the genetic basis of homosexuality.

\section{Context}

My argument is that this dimension of the debates about the ethics of science has been overlooked, and that an investigation of it could help us in addressing specific problems about the context in which science is practised. The issues of context, it seems to me, are two, related to money and power. Now clearly money and power have been issues in professional ethics generally, especially in the 'process' account 
of professions and the sociological critique of professionalism. In science however they take on a particular character. First there is the debate about commercialization, which concerns scientists working for profit-making organizations and the pressures to which that might lead. The second concerns power, and the role of scientists on 'expert' committees.

Attempts have been made to address these issues via the external approach. For example, the profit-making issue has been addressed using concepts such as benefitsharing, as in the HUGO Ethics Committee Statement on Benefit-Sharing (2000). This statement made the fundamental point that there are issues of justice to be addressed here, partly in so far as benefits accruing from scientific research are frequently relying on publicly funded resources to make private profits. As already mentioned, the power issue has been addressed through various mechanisms of public involvement.

However, what needs to be examined is the extent to which different institutional contexts are at variance with the 'internal good' of science, the very point or rationale of the activity. The quotation at the beginning of this paper suggests some universal values that science promotes and which are said to be essential to any truly modern society. To take one of these, constructive subversiveness, it is easy to see that some institutional contexts which require loyalty to the institution would be incompatible with this and which can lead to disaster (cf. Davis, M.K. 1991??).

\section{Conclusion}

I have argued that current debates on the distrust of science have missed what might be an enlightening dimension, that is to set the debate within the context of professional ethics as a whole. Reference to this context shows that it might be helpful to contrast the internal and external approach. Present day debates about the ethics of science, while trying to incorporate public engagement 'upstream' could usefully be informed by discussions about what constitutes the 'internal good' of science. This should not be understood purely in terms of freedom of thought. Analysing this good would also provide a framework for analysing the problems arising from scientific research in particular institutional contexts which might by their very nature undermine the pursuit of the internal good.

\section{References}

Airaksinen, T., 1994. Service and science in professional life. In: Chadwick, R.F. ed. Ethics and the professions. Aldershot, Avebury, 1-3.

Davis, J.K., 1991a. Professions, trades and the obligation to inform. Journal of Applied Philosophy, 8 (2), 167-176.

Davis, M., 1991b. Thinking like an engineer: the place of a code of ethics in the practice of a profession. Philosophy and Public Affairs, 20 (2), 150-167.

Freidson, E., 1994. Professionalism reborn: theory, prophecy and policy. Polity Press, Cambridge.

Goldman, A., 1992. Professional ethics. In: Becker, L.C. ed. Encyclopedia of ethics. St. James Press, Chicago, 1018-1020.

Group of Advisers on the Ethical Implications of Biotechnology GAEIB, 1997. The ethical aspects of the 5th research framework programme. Office for Official Publications of the European Communities, Luxembourg. European Group on 
Ethics Opinions no. 10.

[http://europa.eu.int/comm/european_group_ethics/gaieb/en/opinion10.pdf]

Häyry, H. and Häyry, M., 1994. The nature and role of professional codes in modern society. In: Chadwick, R.F. ed. Ethics and the professions. Aldershot, Avebury, 136-144.

Holdsworth, D., 1994. Accountability: the obligation to lay oneself open to criticism. In: Chadwick, R.F. ed. Ethics and the professions. Aldershot, Avebury, 58-87.

HUGO Ethics Committee, 1996. Statement on the principled conduct of genetic research. Human Genome Organization HUGO, London. [http://www.gene.ucl.ac.uk/hugo/conduct.htm]

HUGO Ethics Committee, 2000. Statement on benefit-sharing. Human Genome Organization HUGO, London. [http://www.gene.ucl.ac.uk/hugo/benefit.html]

Illich, I., 1997. Disabling professions. Boyars, London.

Koehn, D., 1994. The ground of professional ethics. Routledge, London.

Langan, J.P., 1991. Professional paradigms. In: Pellegrino, E.D., Veatch, R.M. and Langan, J.P. eds. Ethics, trust, and the professions: philosophical and cultural aspects. Georgetown University Press, Washington DC, 221-235.

Pellegrino, E.D., 1991. Trust and distrust in professional ethics. In: Pellegrino, E.D., Veatch, R.M. and Langan, J.P. eds. Ethics, trust, and the professions: philosophical and cultural aspects. Georgetown University Press, Washington DC, 69-85.

Serageldin, I., 2002. The rice genome: world poverty and hunger - the challenge for science. Science, 296 (5565), 54-57.

Tur, R.H.S., 1994. Accountability and lawyers. In: Chadwick, R.F. ed. Ethics and the professions. Aldershot, Avebury, 58-87.

Veatch, R.M., 1991. Is trust of professional a coherent concept? In: Pellegrino, E.D., Veatch, R.M. and Langan, J.P. eds. Ethics, trust, and the professions: philosophical and cultural aspects. Georgetown University Press, Washington DC, 159-169.

Vyvyan, J., 1971. The dark face of science. Joseph, London.

Williams, B., 1996. Freedom on probation: a case study of the Home Office enforced changes to the University education and training of probation officers (pamphlet). Association of University Teachers. 